\author{
Journal of NELTA Gandaki (JoNG) \\ (A peer reviewed Open Access Research Journal) \\ ISSN: 2676-1041 [Print] E-ISSN 2822-1559 [Online] \\ Vol. IV Issue (1-2) November, 2021, pp. 119-132 \\ eJournal site: www.nelta.org.np/page/gandaki
}

\title{
Language in Education Policy in Local Governments: A Case of Rupandehi District
}

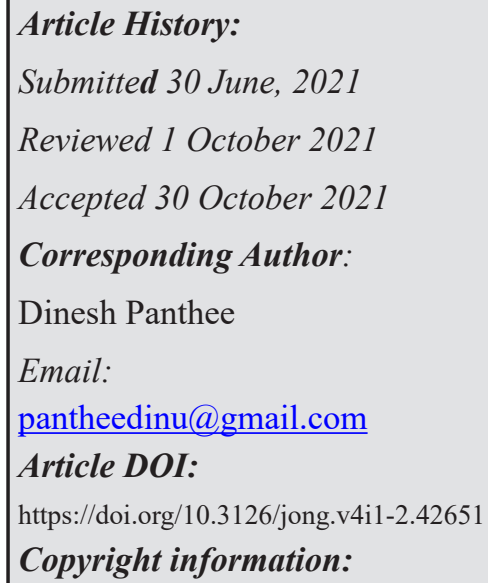

Submitted 30 June, 2021

Reviewed 1 October 2021

Accepted 30 October 2021

Corresponding Author:

Dinesh Panthee

Email:

pantheedinu@gmail.com

Article DOI:

https://doi.org/10.3126/jong.v4i1-2.42651

Copyright information:

Copyright 2021 Author/s and Nepal English Language Teachers' Association, Gandaki Province

This work is licensed under a Creative Commons Attribution- Non

Commercial

4.0 International License

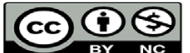

Publisher

Nepal English Language Teachers'

Association Gandaki Province, Pokhara, Nepal

Email: neltagandaki2018@gmail.com

URL.:www.nelta.org.np/page/gandaki
Dinesh Panthee

\section{Abstract}

This paper analyses the position of languages in local education policy. The objectives of this paper were to explore the language in education policies in the local government of Nepal and to find the policymakers' perception toward language in education policy in the local governments of Nepal. I prepared this paper in two ways; by reviewing the secondary documents in which I have gone through the relevant documents of language in the education policy of Nepal historically. It was a case study research design. For primary resources, I selected two local governments of the Rupandehi district as cases and reviewed their policies. For this study, I selected two policymakers of selected local governments of Rupandehi purposively who have been working in the area of local policy-making activity. I performed a depth interview with unstructured interviews based on the education and language policies they had prepared before. The findings of this study revealed that there was a gap between the policy and practice in relation to language in the education policy of local governments. Policies were formulated according to the spirit of the constitution of Nepal respecting all languages but there were lapses in practices focusing on English and Nepali Language. It was also found that policymakers were proactive to promote the local languages but negligence by the user and the policymakers were aware of addressing the linguistic diversity of their municipalities in education policy.

Keywords: EMI, language policy, local languages, multilingual education, policymaker. 


\section{Introduction}

Nepal is a diverse country of multiple cultures and multiple languages. According to the population census of 2011, in Nepal, there are 126 castes/ethnic groups, who speak 123 different languages. These languages are genetically affiliated to four language families: Indo-European (Indo-Aryan), Sino-Tibetan (Tibeto-Burman), Austro-Asiatic, and Dravidian. The Indo-Aryan family is the largest language group in Nepal in terms of the number of speakers. Among these languages, "most Indo-Aryan languages have literate traditions and share a well-developed writing system" (Giri, 2009, p. 34). Nepali, Maithili, Bhojpuri, Tharu, Urdu, and Avadhi are some major languages in this family. The Sino-Tibetan family has the largest number of languages. The majority of languages spoken by the minority ethnic and indigenous people belong to the Sino-Tibetan family. Some major languages in this family include Rai, Limbu (Phyak, \& Ojha, 2019). There are eight major languages in Nepal; Nepali 44.6\%, Maithali 11.7\%, Bhojpuri 5.98\%, Tharu 5.77\%, Tamang 5.11\%, Newar 3.2\%, Magar 2.98\% and Awadhi 2.47\% (Yadav, 2013). The research site is Rupandehi which is one of the growing districts of Nepal. Due to the rapid follow of people, we can find sociolinguist diversity in Rupandehi According to the population census, 2011 Rupandehi district had a population of 880,196 . of these, $36.9 \%$ spoke Nepali, 36.6\% Bhojpuri, $6.4 \%$ Awadhi, $6.3 \%$ Tharu, $4.2 \%$ Magar, 3.5\% Maithili, 2.6\% Urdu, 1.3\% Newari, 1.2\% Gurung and 0.5\% Hindi as their first language. Due to its diversified nature, the local government should be aware while preparing the education policy. The policies must preserve the indigenous languages like Magar, Newar and Tharu spoken at the local level. The Constitution of Nepal article 32(1) has provided each community with the right to get basic education in the mother tongue and to preserve and promote the community's language, script, culture, cultural civility, and heritage. It has taken local government as an autonomous body that can formulate the policies and laws to preserve the language, script, art, culture, and other heritage of their community. The local government has been given the authority to design and develop its education policies, including language policy. Due to high linguistic diversity, local governments find autonomously managing education rather challenging, though they also welcome the new opportunity to address local issues (Poudel, \& Choi, 2021).

Education policy is the collection of laws and rules that govern the operation of the education systems of any government. Language policy is a pressing contemporary issue in multilingual, multiethnic Nepal. It is a multi-layered process, situated within the politico-cultural fabric of society and shaped by policy actors therein (Choi, 2018). In a multilingual society, the complexity involved in language policy is often heightened as language groups and individuals continuously engage in reshaping and redefining the roles of the respective languages involved. In this context, how concerned authority, individual and group, is exercised to shape "the processes of language use, attitudes and ultimately the policies" (Ricento, 2000, p. 206) has received increasing attention.

The government of Nepal has agreed to abide by most of the important human rights documents of the United Nations and granted the right for language communities to operate mother tongue schools. The focus of the use of mother tongues in education has been shifted towards the access and success of quality education. The policymakers have become aware that the education for all (EFA) goals could not be achieved unless the mother tongues are employed as the instructional medium at the early basic education. 
It is expressed explicitly in Nepal's EFA National Plan of Action (2003). The same spirit is reflected in the National Curriculum Framework (2005) and School Sector Reform Plan (2009). The government of Nepal has also promulgated a crucial document for the implementation of the mother tongue-based multilingual education (MTB MLE) programme in Nepal; The Multilingual Education Implementation Guidelines (2010). Nepal along with the nations of the world expressed its commitment to Education for All (EFA) by the year 2015. UNESCO (2011) explained that education for all has been acknowledged as a human right from the very beginning. Article 26 of the Universal Declaration of Human Rights provisioned that everyone has the right to an education that is free, available, and accessible. Where education is not provided in a child's first language this is increasingly seen as a form of discrimination, limiting the application of this right. MTB-MLE provides a clear way for education to be available and accessible to all.

Language in education policy plays a significant role in teaching and learning the language so it has been a major issue of research in the language in education policy worldwide. Nepal is a country with linguistic diversity. The same characteristics are found in local governments of Nepal which has become a centre of discussion in the language in education policy issues. This article aimed to find out the provision and practice of language in education policy at the local government of Rupandehi. It tried to explore the perception of policymakers towards the language in education policy in local government. It also provided an account of the implementation of the language in education policy in local government Nepal. This study was based on the document study which leads to social constructionist research. It tried to add significantly to the body of knowledge already available about the language in education policy and practice from a specific, cultural and historical context of local governments of Rupandehi.

\section{Review of Literature}

For the literature review, I have gone through the report of different education commissions of Nepal and other related documents. Then I reviewed the policies from the pre-1950s to now. I also had gone through the language and education policies of local governments provisioned in their existing laws and prepared the themes based on the practice of those policies.

\section{Pre-1950s : Period of Educational Negligence}

A country with borders close to those of present-day Nepal first emerged in 1769 after a series of military successes by Prithvi Narayan Shah, the first king of the Shah dynasty that held the throne until the abolition of the monarchy in 2007 (Whelpton, 2005). The Kot massacre of royal family members when Junga Badhur Rana and his brothers killed Prime Minister and the relative of the king. Due to this incident, there was the emergence of Autocratic Rana rule in Nepal. The Rana rulers were not interested in developing the feelings of nationalism that often inspire the imposition of national language policies (Burghart, 1984). Besides, they were opposed to widespread education and therefore did not need to set language-ineducation policies. The first statement of language policy in Nepal, made in 1905, supposedly established Nepali as the official language of law and government with the declaration that only documents written in Nepali were legal for use in courts (Eagle, 1999). However, Hutt (1988) notes that no documentation of this declaration has been published. At that time they declared Nepali the only permissible court language, the 
Rana rulers wanted English-language education for their children (Weinberg, 2013). Jung Bahadur Rana traveled to England and elsewhere in Europe in 1850. He was greatly impressed by the educational systems he observed with the power of the English language worldwide (Whelpton, 2005). When he returned he established the Durbar (Palace) School on palace grounds for Rana family, though it later moved off palace grounds and admitted some students from non-Rana, though still elite, families (Eagle, 1999). Thus the first government-run schooling in Nepal was in the medium of English (Weinberg, 2013). At the same time there were practices of religious schooling in Hindu pathshalas and Buddhist gompas, using the mediums of Sanskrit and Tibetan respectively (Eagle, 1999; Phyak, 2011). The medium of instruction of the first higher education center Trichandra College was English. Educational policy at the Ranas period served to limit education to elites, mostly their family. For them the language of education was English.

\section{During the 50s: Period of Instability}

Rana's rule ended in 1950 with the establishment of democracy. The Nepal National Educational Planning Commission (NNEPC) was formed. It was a landmark in Nepalese history because for the first time a policy had been formulated to systematize education. The NNEPC not only universalized primary education but also set up a strong basis for the subsequent development of educational language policies (Phyak, 2011, p. 270). The report supported Nepali as the medium of instruction for schooling, largely for purposes of national integration. The suggested goal was not just to teach academic competence in Nepali, but to develop monolingual Nepali speakers:

It should be emphasized that if Nepali is to become the true national language, then we must insist that its use be enforced in primary school... Otherwise, Nepali, though learned, may remain a "foreign" language rather than the child's basic, thinking language. Local dialects and tongues, other than standard Nepali, should be banished from the school and playground as early as possible in the life of the child. (NNEPC, 1956, p. 96)

The democratic government did not go smoothly during that time, political instability led to the establishment of five different cabinets in five years. The government seemed to be a failure and king Mahendra started the Panchayat system in 1962.

\section{Panchayat era (1962-1990): Period of One Language, One Nation}

King Mahendra created the Panchayat system of so-called party less democracy, which concentrated all real power under the king, which would provide the stability that Nepal needed for national development (Burghart, 1984). It was the time that Nepal's government became interested in cultural unification. The slogan of Ek bhasha, ek bhesh, ek dharma, ek desh (one language, one way of dress, one religion, one nation) summarized the goals of the Panchayat government, which attempted to spread Nepali, Hinduism, and other symbols of the nation throughout the country to create a unified national identity (Rai et al., 2011). The goal was the assimilation of people with varied cultural and linguistic practices into a Nepali identity based on the cultural practices of elite, high-caste hill Hindus (Onta, 1996).

Another major education policy was the National Education System Plan (NESP), established in 1971 and implemented in the five years of inception. The NESP was obvious about the aims of assimilation 
and homogenization, stating the goals of education as:

to strengthen devotion to the crown, country, national unity, and the panchayat system, to develop uniform traditions in education by bringing together various patterns under a single national policy, to limit the tradition of regional languages, to encourage financial and social mobility, and to fulfill manpower requirements essential for national development. (NESP, 1971)

Under this policy, and throughout the Panchayat era, the goals of education were to promote development through the unification of the nation under one language and culture. From the language policy perspective, Panchayat was the darkest age as languages other than Nepali were banned not only in the classroom but also in the playground following the doctrine one nation, one language, one religion adopted by the country at that time. Due to monolingual language policy and monolingual education policy explicitly aimed at the elimination of multilingualism in the period 1952-1990, many Nepalese who were not L1 Nepali speakers internalized feelings of inadequacy and shame attached to their own mother tongues which were increasingly viewed both by Nepali speakers and non-Nepali speakers or Nepali L2 speakers themselves as 'the speech of the illiterate' and 'the dialect of the jungle' (Malla 1979, p. 112; Hutt 1986, p.6). Many have seen this as the outcome of a conscious policy of social exclusion (Phyak 2011, p. 269; Giri 2011).In compliance with this doctrine, the nation-state nationalized and standardized the education system through the National Education System Plan (NESP) in 1969. With this plan, the curricula for various levels of education were designed, and textbooks were prepared in the Nepali language which was the sole medium of instruction. As a result, many indigenous, tribal, or minority children were not motivated to go to school, and even if they joined a school they could not perform as well as the children from the Nepali-speaking community could which consequently forced them to leave schools (Awasthi, 2004).

\section{Post-1990: The Right to Education in the Mother Tongue}

The Panchayat system ended with Jana Aandolan and their established democracy in 1990. The newly formed constitution recognized Nepal as a multicultural and multilingual country. The Constitution of 1990 contained a major shift in language policy at the constitutional level, stating:

The Nepali language in the Devanagari script is the language of the nation of Nepal. The Nepali language shall be the official language. All the languages spoken as the mother tongue in the various parts of Nepal are the national languages of Nepal (Constitution of Nepal, 1990).

This was the first time that languages other than Nepali received constitutional recognition as legitimate elements of the nation. At the same time, this formulation maintains the dominance of Nepali over other languages spoken in the country by keeping Nepali as the only national language (Phyak, 2011). In this constitution, the educational and cultural rights were explicitly extended to Nepal's minorities in the constitution, though again these provisions were not entirely straightforward. The relevant 18 and 26 articles state:

Cultural and Educational Rights (1) each community residing in the Kingdom of Nepal shall have the right to preserve and promote its language, script, and culture. (2) "Each community shall have the 
right to operate schools up to the primary level in its mother tongue for imparting education to its children" (Constitution of Nepal, 1990).

The constitution of Nepal 1990 provided the legal bedrock for the promotion of local languages by making a provision for mother-tongue education at the primary level (Article 18.2) and by guaranteeing all communities. The Interim Constitution of Nepal (2007) is another important landmark for the language policy of Nepal. It has clearly stated that Nepal is a "multiethnic, multilingual, multi-religious, and multicultural nation" (Part I, Article 3) and enshrined the following provisions: "All the languages spoken as the mother tongue [first language] in Nepal are the national languages of Nepal. The Nepali language in the Devnagari script shall be the official language". The Ministry of Education also legitimized English as the medium of instruction (EMI) policy for private schools in its revised educational act in 2006.

The 2015 Constitution redefines Nepal's identity as a "multilingual, multiethnic and multicultural country". In addressing the linguistic rights of ethnic and indigenous minorities' people, the constitution has also removed the previous discriminatory distinction between Nepali as "the language of the nation" and other local languages as "national languages" (Phyak, 2011; Weinberg, 2013). As Anderson (1991) argues, the standardization and promotion of one language as a national language support the ideology of the nation-state as an "imagined community of homogenous people". The constitution also guarantees the right of communities to protect, preserve and promote mineralized languages and states that citizens will not be discriminated against based on their linguistic, ethnic, political, and religious backgrounds (Phyak \& Ojha, 2019).

The provision is contradictory in itself. On the one hand, it ignores the use of mother tongues while giving a focus on Nepali and English but on the other hand, it loosely states the possibility of education in mother tongues serration of their culture, scripts, and languages as a fundamental right (Article 26.2). Certain provisions are provisioned in the constitution of Nepal 2015 that granted the right to language in article 32 as 1 "every person and community shall have the right to use their languages". 3 "Every Nepalese community residing in Nepal shall have the right to preserve and promote its language, script, culture, cultural civilization, and heritage". In the same way, the Act Relating to Compulsory and Free Education (2018) has provisioned the following provision in its article 26 on the topic of Language of instruction: "the medium of instruction to be provided by the schools shall be the Nepali language, English language, or both the languages and mother tongue of the Nepali community concerned". It shows that English is given priority in the Medium of instruction officially.

The constitution devolved considerable powers to local governments, including budgetary allocation decisions and policymaking in areas such as infrastructure, health, education, language. In theory, policymaking at the local level is meant to rely heavily on community participation. In education policy specifically, the new constitution at least nominally devolved to the local level powers. There is no research on how many stakeholders are understanding and internalizing the process of education policy formation in changing contexts. So I tried to study this issue entitled "Language in Education Policy and Practice in Local Governments: A Case of Rupandehi District" with the aim of exploring the policy and practice of language in education policies in the local government of Nepal. 


\section{Methodology}

This study was based on a qualitative research design. I used a case study design which is found in many fields in which the researcher develops an in-depth, multi-faceted understanding of a complex issue in its real-life context Creswell (2014). I selected two local governments of Rupandehi as cases purposively. The first one was one of the sub-metropolitan city which I indicate M1 and another was a Municipality which I indicate M2. M1 lies in an urban area but M2 lies in the semi-urban territory. The participants in this study were two people's representatives of selected local governments of Rupandehi who have been working in the area of local policy-making activity. The policymakers P1 is the mayor of the sub-metropolitan city (M1) and P2 is a female deputy-mayor of Municipality M2. She is from Magar (indigenous) community. I selected them purposively assuming that they were experienced the phenomenon under study because they were directly involved in making different policies of local governments including education policy. Document-related education policies of selected local governments and unstructured guideline questions related to the topic were research tools for this study. Doing a case study is developing a rich and in-depth analysis of a case and its settings so I collected the data by taking in-depth interviews of the participants using unstructured guideline questions. My questions were directed to the participant's experiences, feelings, beliefs, and convictions about the theme in question related to language in education policy. During the study, the participants' real names have been disclosed in accordance with research ethics.

The experience of two people's representatives of Rupandehi was investigated. A small number of participants with a rigorous analysis was sufficient because the study was of an exploratory nature (Daniel, 2012). I analyzed the collected data descriptively developing themes on the basis of the response of the participants. I used the thematic analysis in this paper as a descriptive approach with a focus on the experience, which refers to our experiences of the world.

\section{Results and Discussions}

I analyzed and interpreted the collected data qualitatively by making the themes on the basis of interviews, field notes, and other relevant literature about the topic.

\section{Current Situation and Provision of Language in Education Policy in Local Governments}

Most language matters in Nepal have not been planned; they have evolved in response to historical circumstances (Eagle, 1999, p. 4). The educational language policies were also formed in response to social, political, and historical contexts. Tollefson (2002) explains how the language policy debates reflect the struggles for power relations in society. The endorsement of the new Constitution of Nepal (2015) formally transformed the country into a Federal Republic Democratic nation that delegated the authority of decision-making in many educational issues to local governments, i.e., the offices of municipalities and metropolitan cities composed of elected people representative. Nepal has three levels of elected government: federal, provincial (seven provinces), and local (753 municipalities). The local government has been given the authority to design and develop its education policies. Both municipalities consist of diverse ethnic/indigenous groups so we can find linguistic diversity in them. Due to the recent inflow 
of people, the demographic characteristics and ethnic composition of the municipalities have drastically changed, especially since the 1990s. Such changes have affected the cultural, educational, and linguistic aspects of society at large (Poudel \& Choi, 2020, p.6). Mostly spoken language in Rupandehi is Nepali, other languages are Magar, Tharu, Newar, Gurung, Bhojpuri, Hindi, Maithili, Urdu, Avadhi, Chhantyal, Tamang, Thakali, Bangla, Kham, Rai, Rajsthani, Doteli, Kumal, Punjabi, Limbu, Sign Language, etc. The linguistic diversity in sub-metropolitan city M1 consists of $72.74 \%$ of speakers of Nepali, 8.11\% Magar, 5.32\% Tharu, 5.19\% Newar, 2.17\% Gurung, $2.03 \%$ Bhojpuri, $1.88 \%$ Hindi, and 2.75\% Others language speakers (CBS, 2011). Similarly, in the next Municipality M2 has $88.16 \%$ Nepali native speakers, $7.8 \%$ Thru, 2.62 Bhojpuri, 1.45 Newari, $1 \%$ Maithili, and 2\% are other languages speakers (CBS, 2011).

The research site of this study (both municipalities) has prepared their education policy as Municipal Education Act 2018. Article 7 of M1 and M2 have provisioned that the medium of instruction to be provided by the schools shall be the Nepali language, English language, or both languages. Primary education can be given in the mother tongue only. If a foreigner has to study a compulsory Nepali subject while studying in Nepal, he or she may study any other language subject instead of this, if he or she so wishes. Languages [as a subject] shall be taught in the same language. The medium of instruction for English language teaching must be English. Both municipalities have the concept of mono language, bilanguage, and Multi-language education concept for the transformation. (Education Act 2018, p.4, Education Act 2020, p.137). Both municipalities were concerned with state language and education policy and followed that and prepared their education act. Neupane, (2020) stated that the government of Nepal has presented seven important regulations that provide a framework for Nepal's education and language policies. Based on these frameworks, local governments are trying to formulate education policies and trying to mitigate gaps in policies and practices.

\section{Ideological and Socio-Political Aspects of Language Policy in Local Governments}

Language ideologies are conceptualizations about languages, speakers, and discursive practices. Ideological and sociopolitical dimensions affect the language policy in local governments. As stated in the School Sector Reform Plan (SSRP) report, Nepal has been adopting a "trilingual" policy (learners' first language, Nepali, and English) at school level education since 1990 (Saud, 2020). It has not, however, been fully implemented until now. Most schools begin using NMI in the early grades; some schools have fully implemented EMI, while others have implemented both EMI and NMI. Almost all institutional schools of the study areas have been conducting medium of instruction in English since their establishment. But just a few community schools have adopted EMI fully or partially and some are in the process of adopting it. English has always been the language most associated with high social and economic status in Nepal (Phyak, 2016). Participant P1 said:

we are strengthening our schools with technology and encouraging them to implement English as the medium of instruction so that students from poor families should get quality education.

This shows that the local governments are focusing on English as a subject and medium of instruction whatever they have included the provisions about local language and Nepali as well. , Khati (2016, p. 25) 
argued that more extremely, teachers take for granted that teaching in English helps students find a job and participate in the global community. In the same way, Participant P2 said:

It is the demand of the majority of low-class parents to provide EMI in community schools. So we are supporting those English medium schools to develop the English proficiency of the students so that they could compete with private and urban areas schools' students in the future.

Community schools of the study area are shifting into EMI to compete with private schools. As Phyak (2016, p. 210) confirmed, "public schools are shifting to EMI to compete with private schools". So the ideology towards English is positive. EMI has taken a means to provide students with the English language skills which will enable them to get access to enhanced employment opportunities. Saud (2020) stated that the English language has been getting increasing space in the Nepalese education system from general social discourse to micro-level educational policies and practices due to the demands of the parents as social capital along with the influence of globalization and neoliberalism in education.

\section{Perception Towards Language in Education Policy}

Both municipalities have concerns about the national policy of language and education. They prepared the education policy according to the essence of the constitution of Nepal. In this regard participant, P1 stated 'we are sensational to protect local and indigenous language and prepared the policy according to the constitution of Nepal'. The municipalities have mentioned and focused on mother tonguebased education, multilingual education, and English as mediums of instruction but it is very difficult to apply in the real sense. Poudel and Choi (2021, p.7) state that the issues of protection and promotion of the historically residing linguistic diversity have been addressed through the current constitution (Constitution of Nepal 2015) which provides an appropriate legal framework for substantive legal protection for the national indigenous languages as a medium of instruction. In the same way participant P2 showed devotion to protecting the indigenous language and said

we are aware to protect the local language and made the policy according to the constitution of Nepal but it is very difficult to apply the policy because of the fascination with English as an international language and Nepali as an official language.

Local governments have to choose bi- and multilingualism as a minimum requirement to teach children in the beginning grades of basic education for the creation of this strong foundation to take place. But it is very difficult to successfully implement this provision due to the global political economy, interdependence, and diversity of the municipalities. There is a huge challenge for the local governments of Nepal as plans and policies are often not implemented effectively (Kadel, 2015, p. 196). Different research from home and abroad suggested that basic education must begin with the mother tongue of the learner and gradually shift to language(s) of wider communication. Participant P1 said

we are encouraging local people to promote their language but they are not given attention to the languages they send their children to English medium schools from ECD.

It shows the negligence of the local people for the promotion of their languages. As three-level governments stay silent in this regard, parents, teachers, and school management committees are in a 
dilemma as to whether they should continue with their mother tongue-based multi-lingual education policy or switch to English (Phyak, 2013, p. 41).

\section{Practices of Language Policies at Local Governments}

Mother tongue-based multilingual education is a form of multilingual education built on the learners' mother tongue. Kandel (2010) argued that mother tongue-based multilingual education is very important not only to develop a strong educational foundation but also to strengthen the cognitive development of learners as the beginning of education. Mother tongue-based multilingual education helps strengthen the first language and provides a smooth transition from the first language to the second and the third language. In this regard P1 said

providing education in the mother tongue is the best way of educating children at the primary level so we have stated the provision as every Nepali community residing in our municipality shall have the right to acquire education in the mother tongue.

Both municipalities have focused on mother tongue-based and multilingual education as in the constitution of Nepal. Participant P2 said, "mother tongue-based-multi lingual education is important for equitable quality education and lifelong learning for all because it is the natural means of self-expression of the experiences and thoughts learned in childhood". Mother tongue-based multilingual education begins in the language that the learner speaks most fluently, and then gradually introduces other languages. UNESCO (2011) positioned that MTB-MLE enables life-long learning in a learner's home language provides a solid foundation on which other languages and skills can be successfully built. Phyak (2011, p.128) argues that MTB-based MLE policy is transformative. It has the potential to contribute to social development. It bridges the gap between community and school and recognizes the identity, epistemology, and voices of local communities. MLE also helps to create positive relationships between individuals and society. It helps to generate good and productive citizens who can promote and establish a democratic system for the progressive development of Nepal. A harmonious environment between communities will be achieved and peacebuilding will be facilitated as ethnic and community languages gain equal respect and status alongside other languages. UNESCO (2011) referring to Skutnabb- Kangas (2003) states that if teaching is in a language that an indigenous child does not know, the child sits in the classroom for the first 2-3 years without understanding much of the teaching. That is why many children leave school without learning either of the languages or almost without any knowledge of content. So Language-in-education policymaking is complicated primarily due to its unique demographic structure, i.e., multilingual and multiethnic population of the municipalities. The state and local governments are focusing on MTB-MLE policies but the parents are not emphasizing it. Parents are not convinced of the value of the MLE programme. They believe that EMI is the demand of the world to take our teachers and learners in the global market since EMI enhances exposure to a huge resource of knowledge, by which teachers and learners can be updated and exposed with methodological shift, updated knowledge, science, and technology, and world interconnectedness Poudel (2021, p.53). It is necessary to convince the people to apply MT-MLE education so that students get easier access to contextual learning materials and they can maintain the values, cultural background, and 
identity of their families and communities. They will be able to share a wide range of cultural experiences in literature, entertainment, religion, and their interests with other linguistic and cultural groups. As Baker (2011) states that the ability to speak the mother tongue as well as the national language and international language creates a much wider range of life choices for individuals but can also achieve national unity.

\section{Positive Attitude towards Local Languages but Focus on EMI}

Both of the participants have a strong positive attitude toward the protection of local and indigenous languages. They respect the local languages spoken by their municipalities. They feel more prestigious to protect and promote local culture, language, and art. But local people themselves are embarrassed about speaking their native languages in the presence of speakers of the dominant language. Both argued that teaching children in their mother tongue has created a children-friendly atmosphere in the school but P1 claimed 'Parents were not convinced to send their children to their mother tongue-based school even Nepali medium school.' There is a tendency of sending their children to English medium school because they believe that studying English medium gives better results. P2 argued that her municipality encouraged English medium teaching since English is an international language and learning it would help students in the long run. Phyak, (2013) states that parents have a mindset that their children receive quality education only when they go to private schools wearing a tie, tidy uniform, belt, and school shoes, and speak some English words from the early grades. He further claimed that there are few awareness-raising activities and effective mechanisms to involve the community in the implementation of the policy. "We found ways to improve the quality of education with English as the medium of instruction," P2 said. In the same way, P1 claimed "We are allocating enough budget to strengthen community schools to improve English as a medium of instruction". So quality education is now being assessed in terms of teaching in the English medium particularly in institutional schools and some of the community schools of Nepal, and since this has remained an unquestioned medium in higher education, it is imperative to study the issue of access and quality of education through mother tongue education in Nepal. Due to the influence of English as the medium of instruction, most parents send their children to private English medium schools. Ghimire (2011, p. 37) argued that the choice of English in education had direct significance to the power relation in Nepali society. English education might prepare a group of elites different from ordinary people. Private schools of Nepal are attracting students in the name of quality education with English as the medium of instruction. In the same way, to attract a large number of pupils, public schools in Nepal are transferring the medium of instruction to English, and English as a medium of instruction has been applied without any logical standards. Macaro and Akincioglu's (2018) claimed that EMI increases unnecessary cognitive load and encourages rote learning due to the poor proficiency of practitioners in the language. We must start confronting the myths because we have crossed limits and entered a farcical social juncture whereby community schools are beginning to switch to the English medium to convince parents that they too can deliver "quality" education just by making that switch.

\section{Conclusion and Implications}

Language policy is the set of laws, regulations, or rules enacted by an authoritative body (like 
a government) as part of the language plan. The finding of this study shows language policy is an interdisciplinary perspective integrating the historical, ideological, socio-political, educational, and institutional systems. Language policy and planning is a multi-layered process that is shaped by policy actors within the politico-cultural situation of society. Nepal is struggling to implement its educational policies and plans through developing local curriculum in local languages. To be a multilingual and multiethnic country Nepal is facing the complexity of language policy-making in education. The Nepalese Constitution, promulgated in 2015 , legally turned the country into a federal republic democratic nation, delegating decision-making authority over many educational concerns to local governments. The local government has been preparing the policies as per the constitution of Nepal. Policymakers are committed to developing contextually realistic, sustainable, and efficient policymaking that justifies the use of mother tongues, English as the medium of instruction, the national language, and the global language in a multilingual context. They have tried to maintain the cultural and linguistic diversity of their municipality. They are struggling to implement language in educational policies and plans. They are proactive in protecting and promoting the local language through education but it is a bitter truth that local people are negligent toward the first languages but the emphasis on English. So there is a Shifting of MOI from Nepali to English due to parental demand and pressure. They believe that English is a must for further study, employment, use of modern technology, better result, etc. Due to the development of information science and technology, linked to globalization and languages of wider communication such as English, plays a key role in education. Even though the local governments have provisioned many provisions to respect the local language but students and parents are not positive about the MTB -MLE policies. They only focused on English as a medium of instruction and as the subject.

\section{References}

Anderson, B. (1991). Imagined communities: Reflections on the origins and spread of nationalism. Verso Publication. Awasthi, L. D. (2004). Exploring monolingual school practices in multilingual Nepal [Unpublished doctoral dissertation]. Danish University of Education.

Baker, C. (2011). Foundations of bilingual education and bilingualism. Multilingual Matters LTD.

Burghart, R. (1984). The formation of the concept of nation-state in Nepal. Journal of Asian Studies, 44(1), 101-125. https://doi.org/10.2307/2056748

CBS. (2011). National Population and Housing Census 2011. Government of Nepal National Planning Commission Secretariat Central Bureau of Statistics. http://cbs.gov.np/wp-content/uploads/2012/11/National\%20Report.pdf Choi, T. H. (2018). Implementation and impact of language-in-education policies: Insights from South Korea and Hong Kong. In Kennedy, K. J., \& Lee, J. C. K. (Eds.), Routledge international handbook of schools and schooling in Asia (pp. 518-524). Routledge. https://doi.org/10.4324/9781315694382

Creswell, J. W. (2014). Qualitative, quantitative, and mixed methods approach. Sage.

Daniel, J. (2012). Sampling essentials: Practical guidelines for making sampling choices. Sage.

Eagle, S. (1999). The language situation in Nepal. Journal of Multilingual and Multicultural Development, 20(4-5), 272-327. http://dx.doi.org/10.1080/01434639908666382

Ghimire, L. (2011). Ideologies in the educational language policies of Nepal. Nepalese linguistics, 26, 36-44.

Giri, R. A. (2009). The politics of 'Unplanning' of languages in Nepal. Journal of NELTA, 32-44. https://doi. 
org/10.3126/nelta.v14i1.3089

Giri, R. A. (2010). Cultural anarchism: The consequences of privileging languages in Nepal. Journal of Multilingual and Multicultural Development, 31(1), 87-100.

Government of Nepal (2003). Education for all: National Plan of Action. Ministry of Education and sports, Nepal National Commission for UNESCO

Government of Nepal (2009). School Sector Reform Plan 2009-2015. Ministry of Education.

Government of Nepal (2010). bahubhasik sikshya karya kram karyanwayan nirdeshikaa (Multilingual Education Program Implementation guideline). Ministry of education.

Hutt, M. (1986). Diversity and change in the languages of highland Nepal. Contributions to Nepalese Studies, 14(1), $1-24$.

Hutt, M. (1988). Nepali: A national language and its literature. Sterling Publishers and School of Oriental and African Studies. https://eprints.soas.ac.uk/id/eprint/3000

Kadel, P. (2015). Reviewing multilingual education in Nepal. Multilingual and Development, 189-204.

Khati, Ashok Raj. (2016). English as a medium of instruction: My experience from a Nepali Hinterland. Journal of NELTA, 21(1-2), pp. 23-30. https://doi.org/10.3126/nelta.v21i1-2.20198

Macaro, E., Akincioglu, M. (2018). Turkish university students' perceptions about English medium instruction: Exploring year group, gender and university type as variables. Journal of Multilingual and Multicultural Development, 39(3), 256- 270.

Malla, K. P. (1979). The intellectual in Nepalese society. The Road to Nowhere. Shajha Publication.

Nepal Law Commission. (1990).Constitution of the Kingdom of Nepal: His Majesty's Government of Nepal.

Nepal Law Commission. (2007). Interim Constitution of Nepal. Government of Nepal.

Nepal Law Commission. (2015). The constitution of Nepal. Government of Nepal.

NESP. (1971). National Education System Plan (1971- 1975). Ministry of Education, HMG/ Nepal.

Neupane, P. (2020). Policy Framework for Education Development in Nepal. International Education Studies, 13(1), 89-97. ERIC. https://eric.ed.gov/?id=EJ1239485

NNEPC. (1956). Education in Nepal: Report of the Nepal National Educational Planning Commission. Bureau of Publications, College of Education.

Onta, P. (1996). Ambivalence denied: The making of rastriya itihas in Panchayat era textbooks. Contributions to Nepalese Studies, 23(1), 213-254. http://himalaya.socanth.cam.ac.uk/collections/journals/contributions/pdf/ CNAS_23_01_13.pdf

Paudel, P. (2021). Using English as a Medium of Instruction: Challenges and Opportunities of Multilingual Classrooms in Nepal. Prithvi Journal of Research and Innovation, 43-56. https://doi.org/10.3126/pjri.v3i1.37434

Phyak, P. (2013). Language ideologies and local languages as the medium-of-instruction policy: A critical ethnography of a multilingual school in Nepal. Current Issues in Language Planning, 14(1), 127-143.

Phyak, P. B. (2011). Beyond the façade of language planning for Nepalese primary education: monolingual hangover, elitism, and displacement of local languages? Current Issues in Language Planning, 12(2), 265-287. https:// www.tandfonline.com/doi/abs/10.1080/14664208.2011.584203

Phyak, P. B. (2016). Local-global tension in the ideological construction of English language education policy in Nepal. In R. Kirkpatrick (Ed.), English language education policy in Asia (pp. 199-218). Springer. https://doi. org/10.1007/978-3-319-22464-0_9

Phyak, P., \& Ojha, L. P. (2019). Language education policy and inequalities of multilingualism in Nepal. The Routledge international handbook of language education policy in Asia, 341-354. https://doi.org/10.4324/9781315666235 
Poudel, P. (2019). The medium of instruction policy in Nepal: Towards critical engagement on the ideological and pedagogical debate. Journal of Language and Education, 5(3). https://doi.org/10.17323/jle.2019.8995

Poudel, P. P., \& Choi, T. H. (2021). Policymakers' agency and the structure: the case of the medium of instruction policy in multilingual Nepal. Current Issues in Language Planning, 22(1-2), 79-98. https://www.tandfonline. com/doi/abs/10.1080/14664208.2020.1741235

Rai, V. S., Rai, M., Phyak, P., \& Rai, N. (2011). Multilingual education in Nepal: Hearsay and reality. A report UNESCO. https://bangkok.unesco.org/content/multilingual-education-nepal-hearsay-and-reality-report

Ricento, T. (2000). Historical and theoretical perspectives in language policy and planning. Journal of sociolinguistics, 4(2), 196-213. https://onlinelibrary.wiley.com/doi/abs/10.1111/1467-9481.00111

Saud, M. S. (2020). English medium public schools in Nepal: A new linguistic market in education. LLT Journal: A Journal on Language and Language Teaching, 23(2), 319-333. https://e-journal.usd.ac.id/index.php/LLT/ article/view/2571

Tollefson, J. W. (2002). Language policies in education: Critical issues. Mahwah: Lawrence Erlbaum associate Inc. https://books.google.com.np/books

UNESCO. (2011). Multilingual education in Nepal: Hearsay and reality? A report. https://bangkok.unesco.org/content/ multilingual-education-nepal-hearsay-and-reality-report

Weinberg, M. (2013). Revisiting history in language policy: The case of the medium of instruction in Nepal. Working Paper in Educational Linguistics, 28 (1), 61-80. https://repository.upenn.edu/wpel/vol28/iss1/6/

Whelpton, J. (2005). History of Nepal. Cambridge University Press. https://www.cambridge.org/core/books/history-of Nepal/

Yadav, R. N. (2013). Language Planning and Language Ideology: The Majority and Minority Dichotomy in Nepal. Tribhuvan University Journal, 28(1-2), 197-202. https://doi.org/10.3126/tuj.v28i1-2.26242

Mr. Dinesh Panthee is an assistant professor of English Education at Sahid Narayan Pokharel Ramapur Campus Rupandehi. For his credit, some articles have been published in national journals and received various training on academic writing and English language teaching. His areas of interest include English language teaching, teacher professional development, educational and social research, article writing and editing journal. local curriculum and textbook development 